\title{
Cultivar and Night Temperature Affect Severity of Anthracnose on Euonymus fortunei
}

\author{
Stephanie S. Ningen ${ }^{1}$ and Janet C. Cole ${ }^{2}$ \\ Department of Horticulture and Landscape Architecture, Oklahoma State \\ University, Stillwater, OK 74078-6027
}

\author{
Kenneth E. Conway ${ }^{2}$ \\ Department of Entomology and Plant Pathology, Oklahoma State University, \\ Stillwater, OK 74078
}

Additional index words. Colletotrichum gloeosporioides, growth chamber, wintercreeper euonymus

\begin{abstract}
Effect of night temperatures on the severity of Colletotrichum gloeosporioides (Penz.) Penz. \& Sacc. on Euonymus fortunei (Turcz.) Hand.-Mazz. rooted cuttings of 'Emerald Gaiety', 'Canadale Gold', and 'Emerald 'n Gold' was investigated. Uniform cuttings were exposed to day temperatures of $35.3^{\circ} \mathrm{C}$ and night temperatures of $19.3^{\circ} \mathrm{C}$ or $28.6^{\circ} \mathrm{C}$ in growth chambers. Plants exposed to a $28.6^{\circ} \mathrm{C}$ night temperature had higher disease ratings than those exposed to a $19.3^{\circ} \mathrm{C}$ night temperature. 'Emerald Gaiety' was damaged least by $C$. gloeosporioides compared to 'Canadale Gold' and 'Emerald 'n Gold'. Disease ratings on all cultivars increased linearly over the 6-week experimental period.
\end{abstract}

Euonymus fortunei is an evergreen, perennial landscape plant that is popular with consumers and in the landscape industry (Turner, 1997). Anthracnose, caused by Colletotrichum gloeosporioides (Penz.) Penz. \& Sacc., was first reported by Mahoney and Tattar (1980a, 1980b) on E. fortunei in New England nurseries and was later noted in nurseries in Florida (Chase, 1983). Anthracnose on $E$. fortunei has become an increasing problem over time for nursery producers and currently causes estimated losses of $\$ 200,000$ to $\$ 500,000$ annually for one eastern Oklahoma nursery (D. Dunn, personal communication). Common anthracnose symptoms on E. fortunei include leaf drop, leaf lesions, stem lesions, and stem dieback. Colletotrichum gloeosporioides has been identified as the causal fungus of anthracnose on E. fortunei (Mahoney and Tattar, 1980b). During the growing season, the fungus consists of a mass of hyphae within lesions on the stem and leaf tissue, which produces conidia on the host surface that cause secondary infection (Agrios, 1997; Alexopoulos et al., 1996). Colletotrichum gloeosporioides flourishes under high humidity and high temperature conditions (Agrios, 1997).

The objective of this study was to determine the effect of night temperature on anthracnose severity on three cultivars of E. fortunei. No previous studies have evaluated the effect of temperature on the incidence and severity of C. gloeosporioides on E. fortunei.

Received for publication 27 June 2003. Accepted for publication 4 Dec. 2003. Approved for publication by the Director, Oklahoma Agricultural Experiment Station. This research was supported under project OKL02324. Plants, growing media, and partial funding for this project were provided by Greenleaf Nursery Co.

${ }^{1}$ Former Graduate Research Assistant. ${ }^{2}$ Professor.

\section{Materials and Methods}

Uniform, rooted cuttings of E. fortunei 'Emerald Gaiety', 'Canadale Gold', and 'Emerald 'n Gold' (Greenleaf Nursery Co., Park Hill, Okla.) having two to three nodes were randomly taken from presumably anthracnose-infected mother plants in the field. High incidence of disease in the field eliminated the need to further inoculate. Cuttings were placed into two growth chambers (Model no. I-35LL; Percival Mfg. Co., Boone, Iowa) with temperatures $( \pm \mathrm{SE})$ of $35.3 \pm 0.01{ }^{\circ} \mathrm{C}$ during the day and 14-h daylengths. One chamber had a night temperature of $19.3 \pm 0.02{ }^{\circ} \mathrm{C}$ and the other had a night temperature of $28.6 \pm 0.11$ ${ }^{\circ} \mathrm{C}$. Cuttings were planted in 5.1-cm-diameter pots in media consisting of 6 pine bark : 1 sand amended with $3 \mathrm{~kg} \cdot \mathrm{m}^{-3}$ dolomitic lime, 391 $\mathrm{g} \cdot \mathrm{m}^{-3}$ 0N-20P-0K (triple superphosphate), $215 \mathrm{~g} \cdot \mathrm{m}^{-3} 0 \mathrm{~N}-0 \mathrm{P}-46 \mathrm{~K}(\mathrm{KCl}), 111 \mathrm{~g} \cdot \mathrm{m}^{-3}$ trace elements (Frit 504 HF; Frit Ltd., Cambridge, U.K.), $889 \mathrm{~g} \cdot \mathrm{m}^{-3} \mathrm{FeSO}_{4}, 741 \mathrm{~g} \cdot \mathrm{m}^{-3} 46 \mathrm{~N}-0 \mathrm{P}-0 \mathrm{~K}$ (urea), and $1.2 \mathrm{~kg} \cdot \mathrm{m}^{-3}$ iron oxide (GU-49; Master Builders,Cleveland, Ohio). Forty-eight plants were placed in each growth chamber. Each chamber was subdivided into two shelves of plants, each containing a completely randomized arrangement of 24 plants (eight of each cultivar). Each shelf was lit by two 20W lightbulbs (Sylvania Gro-Lux, Danvers, Mass.). Average photosynthetic photon flux was $28 \mu \mathrm{mol} \cdot \mathrm{m}^{-2} \cdot \mathrm{s}^{-1}$.

Plants were irrigated every $48 \mathrm{~h}$ by applying $40 \mathrm{~mL}$ of tap water to the surface of the growing medium for each plant. Temperature and relative humidity were recorded every 10 min using data loggers (WatchDog model 450; Spectrum Technologies, Plainfield, Ill.). Relative humidity $( \pm \mathrm{SE})$ averaged $80.9 \% \pm 0.2 \%$ in chambers with a $19.3{ }^{\circ} \mathrm{C}$ night temperature, and $81.3 \% \pm 0.2 \%$ in chambers with a 28.6
${ }^{\circ} \mathrm{C}$ night temperature. Severity of disease in the plants was rated weekly for 5 weeks using the Horsfall-Barratt rating system (Horsfall and Cowling, 1978). The rating scale ranged from 1 to 12 , corresponding to the following disease incidences: $1=$ no diseased tissue; $2=1 \%$ to $3 \%$ diseased tissue; $3=3 \%$ to $6 \%$ diseased tissue; $4=6 \%$ to $12 \%$ diseased tissue; $5=12 \%$ to $25 \%$ diseased tissue; $6=25 \%$ to $50 \%$ diseased tissue; $7=25 \%$ to $50 \%$ disease-free tissue; $8=$ $12 \%$ to $25 \%$ disease-free tissue, $9=6 \%$ to $12 \%$ disease-free tissue; $10=3 \%$ to $6 \%$ disease-free tissue; $11=1 \%$ to $3 \%$ disease-free tissue; and $12=$ no disease-free tissue. Samples of leaves and stems with disease symptoms were collected from plants throughout the experiment and placed on potato dextrose agar to confirm that $C$. gloeosporioides was the cause of the symptoms observed.

The experiment was repeated with the night temperature treatments reversed between the growth chambers. This was done to ensure that no variability existed between growth chambers. Data were analyzed together as one experiment. Asplit-split plot experimental design was used with 16 replications. Cultivar was the whole-plot treatment, temperature was the sub-plot treatment, and time (weeks in the chamber) was the sub-sub-plot treatment. Analysis of variance procedures were performed on the data. Trend analyses were used to detect relationships among rating dates for each cultivar (SAS Institute, Cary, N.C.).

\section{Results and Discussion}

Anthracnose on E. fortune i is characterized by discrete, circular, dark brown lesions 0.5 to $3.0 \mathrm{~mm}$ in diameter, with light tan necrotic centers on the upper and lower leaf surfaces (Mahoney and Tattar, 1980b). In this study, anthracnose symptoms included leaf and stem lesions, leaf abscission, and stem dieback.

Disease incidence in commercial production has been observed to be greatest during July and August, when both day and night temperatures are generally high. In past research, fewer anthracnose symptoms were observed on plants at a site with cooler temperatures than at sites with warmer temperatures (Cole et al., unpublished). The present study confirms that disease incidence is less with lower night temperatures. Lower disease ratings (5.4) occurred with a $19.3{ }^{\circ} \mathrm{C}$ night temperature than with a $28.6^{\circ} \mathrm{C}$ night temperature (6.0) $(P=0.02)$.

Previous research noted greater disease severity on 'Emerald 'n Gold' compared to 'Emerald Gaiety'(Mahoney and Tattar, 1980b; LaMondia, 2001). In this study, cultivar interacted with rating week $(P<0.001)$ such that disease ratings did not increase as quickly on 'Emerald Gaiety' as on 'Canadale Gold' or 'Emerald 'n Gold' (Fig. 1). No interaction existed between cultivar and night temperature for any rating week. Nointeraction occurred between temperature and rating week or between cultivar, temperature, and rating week.

From this study, we recommend use of cultivars, such as 'Emerald Gaiety', that appear to be less susceptible to anthracnose, and use 


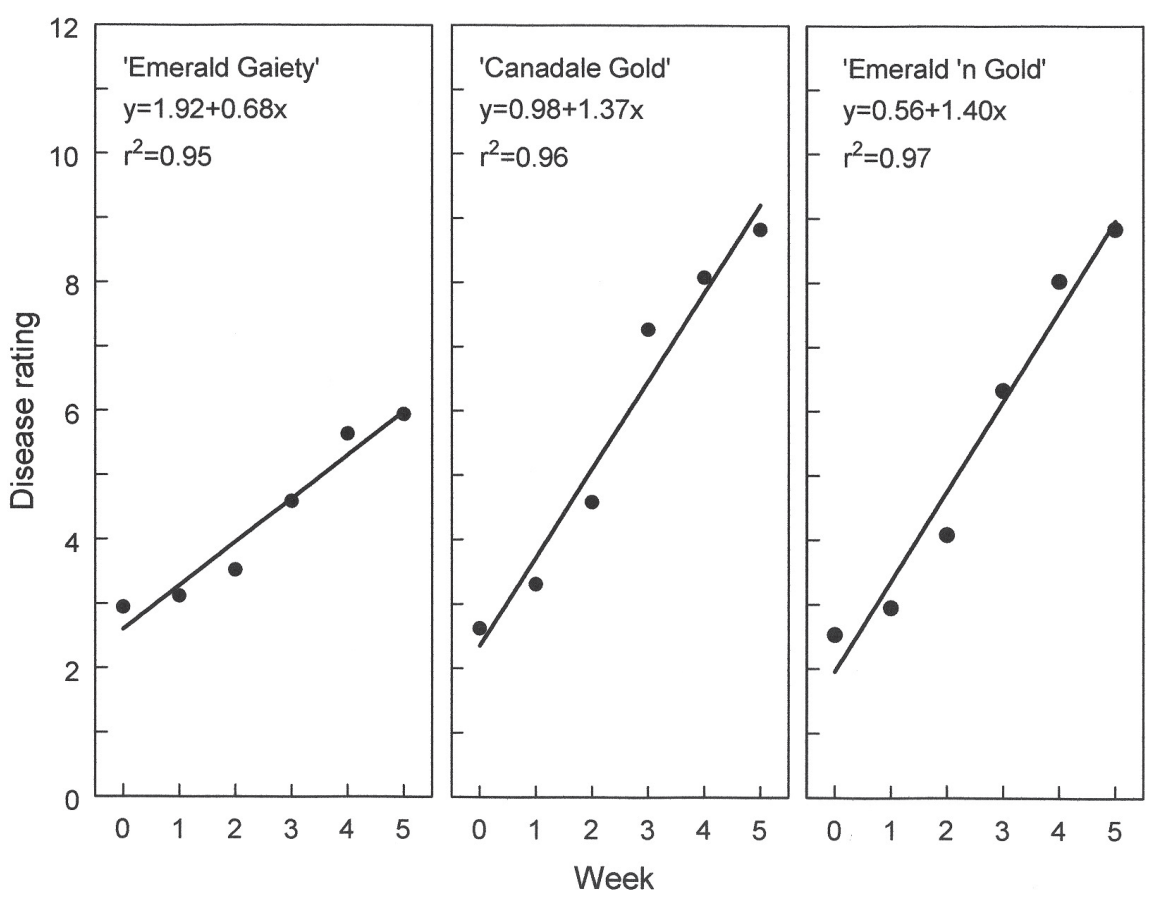

Fig. 1. Anthracnose disease ratings on three cultivars of Euonymus fortunei based on the Horsfall-Barrett rating scale (see text). Plants were rated when placed in growth chambers (Week 0) and at weekly intervals for 5 weeks. of a $19.3{ }^{\circ} \mathrm{C}$ night temperature in propagation and growing structures where temperature control is possible.

\section{Literature Cited}

Agrios, G.N. 1997.Plant pathology. 4thed.Academic Press, San Diego.

Alexopoulos, C.J., C.W. Mims, and M. Blackwell. 1996. Introductory mycology. 4 th ed. Wiley, New York.

Chase, A.R. 1983. Two foliar diseases of Euonymus spp. Foliage Dig. 6(1):14.

Horsfall, J.G. and E.B. Cowling. 1978. Pathometry: The measurement of plant disease, p. 119-136. In: J.G. Horsfall and E.B. Cowling (eds.). Plant disease, an advanced treatis, vol. II. Academic Press, New York.

LaMondia, J.A. 2001. Management of euonymus anthracnose and fungicide resistance in Colletotrichum gloeosporioides by alternating or mixing fungicides. J. Environ. Hort. 19:51-55.

Mahoney, M.J. and T.A. Tattar. 1980a. Causal organism for spot anthracnose disease identified. Amer. Nurseryman 152(13):77-78.

Mahoney, M.J. and T.A. Tattar. 1980b. Identification, etiology and control of Euonymus fortunei anthracnose caused by Colletotrichum gloeosporioides. Plant Dis. 64:854-856.

Turner, R.G., Jr. 1997. Botanica. Random House, New York. 